\title{
Chapter 4 \\ The Exceptional Design of Large Housing Estates in the Baltic Countries
}

Marija Drèmaitė

\begin{abstract}
This chapter discusses Baltic (mostly Lithuanian) mass housing estates as winners of Soviet urban planning and housing competitions; the role of the architect in the field of standardised design; and Western architectural influences in Soviet Baltic housing estate design. In the field of industrialised and standardised housing construction, the role of architects and one-off design is of special interest, because industrialisation and standardisation in Soviet mass housing brought tension between planners of standardised large housing estates and master architects who drew up unique designs for public buildings. Despite the Communist Party declaring in 1955 the importance of mass housing, the Soviet Union's most prestigious state award - the Lenin Prize - was only ever conferred upon one model site: the Lazdynai large housing estate in Vilnius, Lithuania, in 1974. This chapter thus focuses on the involvement and experimentation of Baltic architects in the planning of standardised housing estates; on professional acknowledgment and on the fulfilment of ideological requirements.
\end{abstract}

Keywords Microrayon · Lazdynai - Mass housing $\cdot$ Baltic modernism

\subsection{Introduction}

Reflecting the current interest in regional differences in large processes and phenomena, peripheral histories open up the possibility of seeing other dimensions, local variations and regional adaptations, and are able to change the established narrative frames. Comparative research in post-war mass housing has shed new light on uniformity and standardisation processes by adopting a more focused approach towards regional differences in the former Socialist countries, especially in the areas of East-West technological relations, the appropriation and rejection of Soviet directives, and the importance of local expertise (Kalm and Ruudi 2005;

\footnotetext{
M. Drèmaitè $(\bowtie)$

Department of History, Vilnius University, Vilnius, Lithuania

e-mail: marija.dremaite@gmail.com

(C) The Author(s) 2019

D. B. Hess and T. Tammaru (eds.), Housing Estates in the Baltic Countries,

The Urban Book Series, https://doi.org/10.1007/978-3-030-23392-1_4
} 
Ritter et al. 2012). In a book on prefabrication and the organisation of Soviet industrial construction (Meuser and Zadorin 2015), the authors not only included an analysis of changes in Soviet mass housing production, describing three generations of mass housing and their special characteristics, but also summarised the changing discourse in socialist mass housing studies, moving away from uniformity and standardisation to regional differences. In a comparison of two dissimilar Soviet regions analysed in two recent studies of mass housing - Central Asia (Meuser 2016) and the Baltic Republics (Drèmaite 2017) — regional differences (and reasons for these differences) were discussed. Baltic modernist architecture was perceived as a manifestation of design excellence throughout the entire USSR: the Baltic region was sometimes called 'the inner abroad' or the 'Soviet West' owing to its Western-influenced architectural designs.

In this context, the possibility that the design of large housing estates in the Baltic region was considered exceptional within the Soviet Union has been addressed by several researchers, particularly in light of the Baltic States' relations with - and orientation towards - Western and International Modernism (Maciuika 1999; Ojari 2004; Cinis 2007). A comparison of Baltic and Nordic housing architecture was a particular focus of the Nordic-Baltic research network, which highlighted the important role played by Nordic Modernism in developing Baltic Modernism during the Soviet period (Caldenby and Wedebrunn 2010, 2013). Recent papers discussing specific Estonian aspects of mass housing have emphasised the criticism of mass housing (Kurg 2009), which led to alternative house design solutions (Kalm 2012a), and the role of architects in designing large housing estates (Metspalu and Hess 2018).

This chapter will further explore the role of the architect and the individualised design approach in the field of mass housing, where construction has been largely regulated by standardisation and the economy. David Crowley saw the division between standard and original as one of the most fundamental features shaping the nature of Socmodernism (a term proposed by Crowley) and distinguishing it from Western Modernism (Crowley 2009, pp. 246-258). He proposed dividing post-war socialist architecture into 'Socmodernism 1' and 'Socmodernism 2' based on this distinction. In his conception, 'Socmodernism 1' met the demands issued by Soviet leader, Nikita Khrushchëv, as early as 1954 to supply inexpensive, unembellished industrialised buildings, largely but not only for the sphere of housing. In this sphere architects were expected to behave as technocrats; they were required not to produce buildings but types, with the result that housing design was removed from the sphere of art to engineering (Crowley 2009, pp. 246-247). This thesis is supported by Richard Anderson who also noted that the architectural profession underwent a process of differentiation during this [Khrushchëv's industrialisation] period as it devolved into two principal spheres: 'those who worked primarily in the field of serialized production and those who worked on unique buildings' (Anderson 2015, p. 250).

The tension between serialised and unique design became a long-standing feature of Soviet architectural production. As Mart Kalm put it: 'Standardised designs were already in extensive use during the Stalinist period but became an obsession 
during Khrushchëv's Thaw, when economical building practices became the focus of attention. [...] The more the state demanded standardised designs, the more architects became irritated and felt oppressed by the restrictions' (Kalm 2012b, p. 39).

These observations suggest the hypothesis that regional differences in the standardised architecture of large housing estates could be introduced by local experts proposing unique architectural solutions. It is therefore important to examine how Baltic architects pursued more individualised solutions; how ideological requirements were imposed during this particular period; and how architects proposed solutions for improvement. It is also important to establish how certain professional (or even national ethnic) aspirations were cloaked in a 'correct' Soviet rhetoric and whether there existed alternative ways of securing official acknowledgement of a project.

The main source of material for this chapter is constituted by my interviews with Lithuanian architects Vytautas Čekanauskas and Vytautas Brèdikis. It should be noted, however, that these interviews were conducted in the period between 2006 and 2016, when the architects had been able to reflect on their designs in light of the passage of time and under different political circumstances. I am therefore grateful to John V. Maciuika, who shared his findings from the personal interviews which he conducted with the same architects in 1992.

Archival research was conducted in the Russian State Archives for Literature and Arts in Moscow (RGALI), where the files of the Lenin and Soviet State Prize Committees are stored. Fairly detailed records were kept of each section meeting, though some handwritten corrections on the machine-typed text suggest possible omissions and revisions. Original designs for Lithuanian large housing estates held by the Lithuanian State National Archives, the Vilnius Regional State Archives, and the Lithuanian Archives of Literature and Art were also consulted.

Other materials reviewed for this paper were carefully selected from the All-Union professional journal (Архитектура CCCP-Architecture of the USSR) and the local Lithuanian journal (Statyba ir Architektura-Construction and Architecture). Information about housing in the Soviet period can be found in the descriptive summaries of the 'architectural achievements' of the Soviet period in Estonia (Volkov and Kruusimagi 1972; Volkov 1987), Latvia (Zakamennijs 1966; Krastinš et al. 1987) and Lithuania (Budreika 1971; Minkevičius 1987).

\subsection{A New Type of Apartment Building and a New Type of Soviet Neighbourhood}

After 1955, Nikita Khrushchëv's construction reforms related to industrialisation and standardisation affected the entire system of Soviet architecture. Planning became the responsibility of two government ministries; Gosplan and Gosstroi, each accountable to the USSR Council of Ministers. Gosplan, the State Planning 
Committee, was responsible for national and regional economic planning, which includes investment in construction. Gosstroi, the State Construction Committee, was established in 1955 as the Soviet Union's principal national institution controlling regional and city planning and construction processes. Gosstroi was involved in every phase of the construction process, from planning to general contracting. The system included more than a dozen specialised research and design institutes as well as scores of local design centres. As with their economic counterpart, Gosplan and Gosstroi were replicated at the Soviet republic level in the form of 15 state construction committees, one in each constituent republic (Ruble 1993, p. 239).

Following the Communist Party's 1957 promise to provide every Soviet family with an individual apartment (Decree No. 931, 1957), the development of residential zones became a critical urban planning issue. The restructuring of the Soviet housing construction industry focused on two issues in particular: industrial production of standardised housing types and the creation of a new model of residential district known as the microrayon. Both undertakings were subject to strict regulation by the State Committee of Civil Construction and Architecture (Gosgrazhdanstroi), which was subordinate to Gosstroi.

For many years, the introduction of large-panel house production (known by its Russian acronym, KPD) and the adoption in 1955 of regulations [known as the Construction Norms and Rules (known by its Russian acronym, SNiP)] served as the means for controlling residential design. In the period from 1955 to 1991, the SNiP rules dealing with mass housing were thoroughly revised only four times: in 1957, 1962, 1971 and 1985, resulting in very slow changes in mass housing design (Meuser and Zadorin 2015, p. 21). In 1956, Gosstroi organised an architectural competition for drawing up new types of design for three-, four- and five-storey houses with small apartments. Based on 217 entries, Gosstroiproekt developed model designs which were finally recommended by Gosstroi for universal roll-out and were used for the majority of mass housing designed between 1958 and 1963 (Meuser and Zadorin 2015, p. 168).

State planning institutes in the Soviet Baltic Republics considered Gosstroiproekt's housing series no. 1 as the basis for local designs. Estonprojekt architects in Tallinn, under chief architect Mart Port, designed Estonia's housing series No. 1-317 in 1956 (Ojari 2004, p. 67), and the Lietprojektas group in Vilnius, under chief architect Gediminas Valiuškis, developed local designs (series No. 1-318) for two-, three-, four- and five-storey buildings in 1958 (Peras 1958, p. 34). Another All-Union design (by Giprostroiindustrya) became the basis for the series I-464, the most widespread industrial series both in Soviet mass housing and in the Baltic cities (Meuser and Zadorin 2015, p. 193). I-464 was particularly subject to multiple improvements and local modifications.

Industrialised housing construction was accompanied by a new type of urban planning, the microrayon (micro-district), a Soviet version of the basic neighbourhood unit (Dremaite 2010; Kosenkova 2013). The model of the Soviet microrayon was developed after the architectural competition of Socialist countries in 1960 for the development of the south-western area of Moscow. The event had an 
important mission: to develop new methods for grouping and arranging multi-unit apartment buildings. The 1960 competition was crucial towards affecting changes in residential urban planning, abandoning the system of constructing housing along the perimeter of a city block in favour of a more freestyle arrangement of multi-unit apartment houses.

The competition also focused on social planning, introducing a tiered system of public, cultural and consumer services (Osnovy sovetskogo gradostroitelstva 1967, pp. 168-242). Tiers were based on the estimated needs of 1000 inhabitants and were defined by frequency of use: daily use sites, periodic use facilities (visited two to three times per week), and episodic use facilities, used twice or three times monthly (Fig. 4.1). The core unit of the microrayon was a group of residential buildings for 2000 inhabitants, further grouped into a microrayon with 900012,000 inhabitants. Services usually accessed on a daily basis included kindergartens, schools, food shops, canteens, clubs, housing unit administration services, sports fields and playgrounds. These were all located within the boundaries of a given microrayon, and no further than $400 \mathrm{~m}$ from any one home. All first-tier public buildings were expected to follow standard designs and consist of prefabricated parts. Second-tier facilities, such as cinemas, libraries, department stores and healthcare facilities, were to be built for the larger residential area (made of several microrayons) and intended to be used periodically. Once these new types of large-scale residential districts began to emerge, management and financing had to be transferred from enterprises to municipal authorities and local governments, who then became responsible for both planning and construction. This was perhaps the most significant change in the modernisation of Soviet urban planning.

\subsection{Prefabricated Mass Housing and Microrayons Are Introduced to the Baltic Republics}

In all three Baltic republics, the major state planning institutes were tasked with planning standard residential construction and 'anchoring it in place', i.e. adapting standardised designs to a specific building plot. Departments of standardised design were established at state planning institutes. The first large-panel residential district plan, prepared in 1959 at the Vilnius Urban Construction Design Institute, demonstrated an attempt to arrange buildings on a more open plan, including diagonal placement. Designed by architect Laimutė Elena Bergaitė-Burneikienè, this new residential quarter for drill factory workers consisted of five-storey, elongated rectangular series I-605A (Giprostroiindustrya) buildings with 80 units per structure (Fig. 4.2). Similarly, Tallinn's second prefab housing district, Mustamäe, was constructed with series I-464 apartment blocks (Ojari 2004, p. 67). Designed in 1959 by the State Design Institute Estonprojekt (architects Voldemar Tippel, Toivo Kallas and Lidia Pettai), it followed the principles of freeform planning and standardised design. It was divided into nine microrayons to 


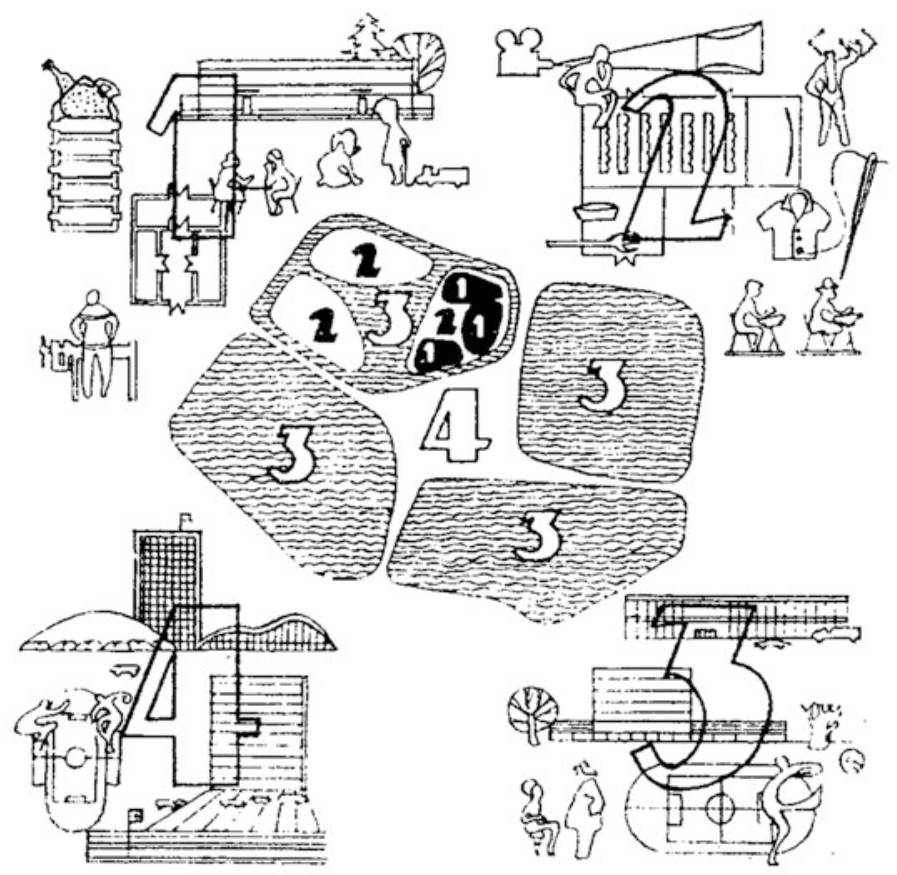

19 pav. Pakopinè kultürinio-buitinio aptarnavimo sistema tarybiniame mieste, suskirstytame i mikrorajonus:

1 - gyvenamụjụ namụ grupé (2000 gyventoju), 2 - mikrorajonas (6-10 tūkst. gyventoju), $3-$ gyvenamasis rajonas (25-50 tükst. gyventojų), 4 - miestas"

Fig. 4.1 Schematic of a tiered system of public cultural and consumer services in a Soviet city: 1 . A group of homes (2000 residents). 2. Microrayon (10,000 residents). 3. Residential area (40,00050,000 residents). 4. A city. Source Minkevičius (1964), p. 40

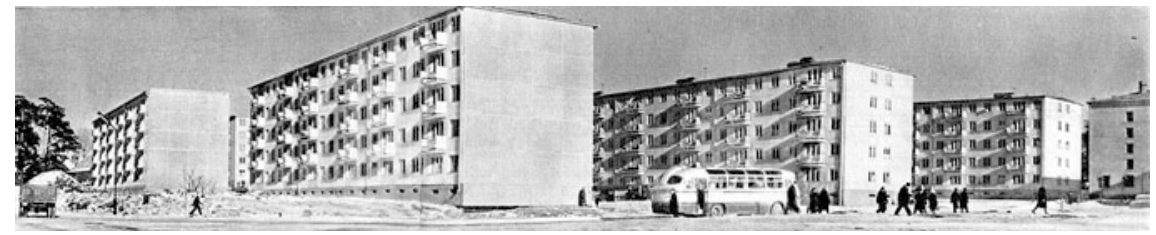

Fig. 4.2 The first prefabricated large-panel buildings (series) built in Vilnius in 1959. Source Naujoji tarybu Lietuvos architektūra (New Architecture of Soviet Lithuania) (1964). Vilnius: Mintis, p. 4 
accommodate 60,000 residents. Each microrayon was arranged around one school, four to six nursery schools and a network of services ranging from post offices to public saunas, all of which would be within walking distance of the residential blocks. Later, custom designed high-rises and apartment buildings were built in Mustamäe.

Āgenskalna Priedes was the first large-scale housing estate in Riga. The first construction stage, with five-storey standard brick houses (locally adapted series No. 1-316), started in 1959 and was completed in 1961 (architect Nikolajs Rendelis). A residential area, a restaurant, commercial buildings and public service facilities were also provided. The second stage of the development started in 1961 with five-storey series I-464-A panel houses. The district retained its historical name. There was an area with several high dunes and clusters of pine trees; however, the dunes were levelled in the construction process and natural features of the district were destroyed (Krastiņš 2013, pp. 83-91).

The three examples mentioned above show that in the first stage of implementing the new directives, standards in prefabricated housing construction and urban planning were followed with little experimentation. Architects recalled that 'architects were hardly involved' (V. E. Čekanauskas, interviewed by John V. Maciuika, 1992), and that work in standardised planning was perceived as neither desirable nor creative (V. E. Čekanauskas, personal communication, December 11, 2006; V. Brèdikis, personal communication, August 2, 2011). In Lithuania, for example, such tasks were delegated to recent graduates who, in turn, hoped to escape their new duties as soon as possible and progress to individualised design. It is also noteworthy that the planning of new microrayons was often delegated to female planners, with comments to the effect that the composition of a microrayon was governed by standards, thus lacking architectural innovation.

By 1961, the Third Congress of Soviet Architects boasted of enormous productivity (165 million $\mathrm{m}^{2}$ of residential floor space created in 1959-1960) but it also took note of significant shortcomings, including 'a lack of creativity in the use of standard designs’ (Архитектура СССР, 1961, no. 6, pp. 3-5). As Dmitry Zadorin has noted, scientific studies have repeatedly attempted to combat the monotony; but the economy was the real reason why all Soviet cities of that era were full of five-storey buildings arrayed in extremely regular patterns (Meuser and Zadorin 2015, p. 167). The architect Albertas Cibas, an official with the Lithuanian Gosstroi, called for measures to attract the best and most experienced architects to work on standardised designs, providing them with a degree of creative liberty, particularly in the adaptation of standard designs for certain sites (Архитектура СССР, 1961, no. 7, p. 7). Decree No. 903 'On Improvement of Design Practice in the Field of Civil Construction, Planning and Construction of Cities', issued by the Soviet Communist Party's Central Committee and Council of Ministers in 1963, indeed encouraged the transfer of responsibilities to regional and local levels. Local design institutes and State building concerns now had an opportunity to implement slight modifications. This all led to experimentation in housing design and microrayon planning. 


\subsection{Experimental Design: The Growth of Local Expertise and the Role of Architects}

In such negotiations, the word 'experimental' played a key role as it had been validated by the 'scientific technological revolution'. David Crowley has noted that architects and designers who could characterise their work as 'experimental' (meaning that an experimental building would provide technical know-how for the rest of the building sector) could bolster their credentials as technical specialists and draw on greater resources and enjoy greater freedoms (Crowley 2009, p. 252).

Indeed, experimental design became a very effective way of introducing improvements to the Soviet residential housing system. The Vilnius Urban Construction Design Institute established a special office for this purpose in 1960. The planning for Burbiškès - a new neighbourhood of Vilnius, which was never constructed-provides an example. Burbiškès was the first mass housing project entrusted to a new generation of young architects-Vytautas Čekanauskas, Vytautas Brèdikis, Jaunutis Makariūnas, Algimantas and Vytautas Nasvytis, who were born in the 1930s and graduated in the mid-1950s - in hopes that they would develop fresh ideas. From 1961 to 1962 , their task was to draw up plans for a residential district in southern Vilnius comprising 30,000 residents, incorporating a three-tier internal organisational structure (Fig. 4.3).

It is important to note that several architects of this group had already earned a reputation as promoters of new ideas. The Nasvytis brothers had designed the breakthrough modernist interior of the Neringa café in Vilnius in 1959. Čekanauskas and Brèdikis had designed the Composers' Union Hall and housing complex with a Nordic touch in 1960. They came from a field of architecture that was valued by the informal hierarchy of the profession. It is also important to

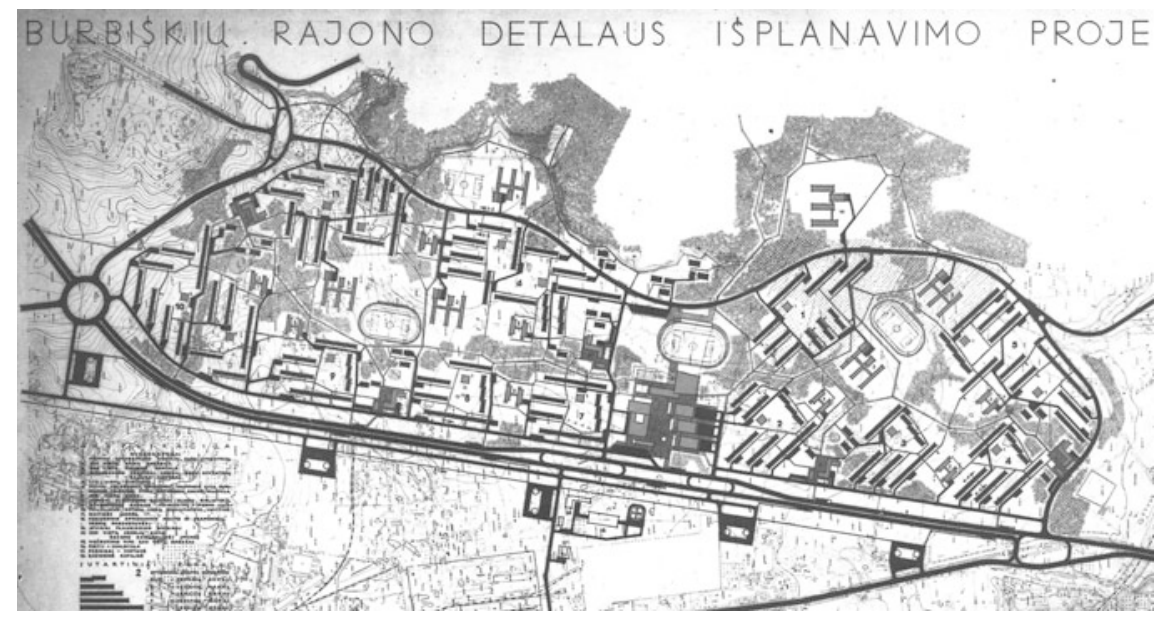

Fig. 4.3 Detailed plan of Burbiškès residential area in Vilnius, 1962. Private collection 
understand the idealism and ambition of the group. According to architects, they wanted to change the standard five-storey residential buildings - to design structures that could be placed on complex terrain and arranged in various different vertical and horizontal combinations, not simply placed in long rows on flat fields. Vytautas Čekanauskas recalls: 'We referred to these [pre-fab panel] buildings simply as "bricks" because of their slab shape and unsightly nature. We wanted to improve these buildings by changing those horrible Russian designs' (V. E. Čekanauskas, personal communication, December 11, 2006).

Architects, working at the same Vilnius Urban Construction Design Institute, supported the ideas of Čekanauskas and Bredikis. Between 1960 and 1965, a group of young architects - Gediminas Valiuškis, Enrikas Tamoševičius and the Nasvytis brothers - drew up the first experimental plans for apartment units and in 1961, organised an internal mini-competition. Vytautas Nasvytis, Jaunutis Makariūnas and Algirdas Jasinskas developed an improved version of the standard I-464 series house, with apartments that could be divided using light sliding partitions or room dividers that also served as closets, allowing for different configurations of each apartment (Figs. 4.4, 4.5, 4.6 and 4.7). However, the price for $1 \mathrm{~m}^{2}$ increased by 5$6 \%$, and the Vilnius factory producing the concrete elements refused to make changes. The Chairman of the Lithuanian Union of Architects complained: 'This is a strange situation - on the one hand, architects are criticised for design flaws, yet on the other hand, their improvements are not accepted.' (Union of Architects Chairman's report 'Architects' tasks in the CPSU Programme' at the Board Plenum, February 2, 1962, Lithuanian Archives of Literature and Art, f. 87, ap. 1, c.

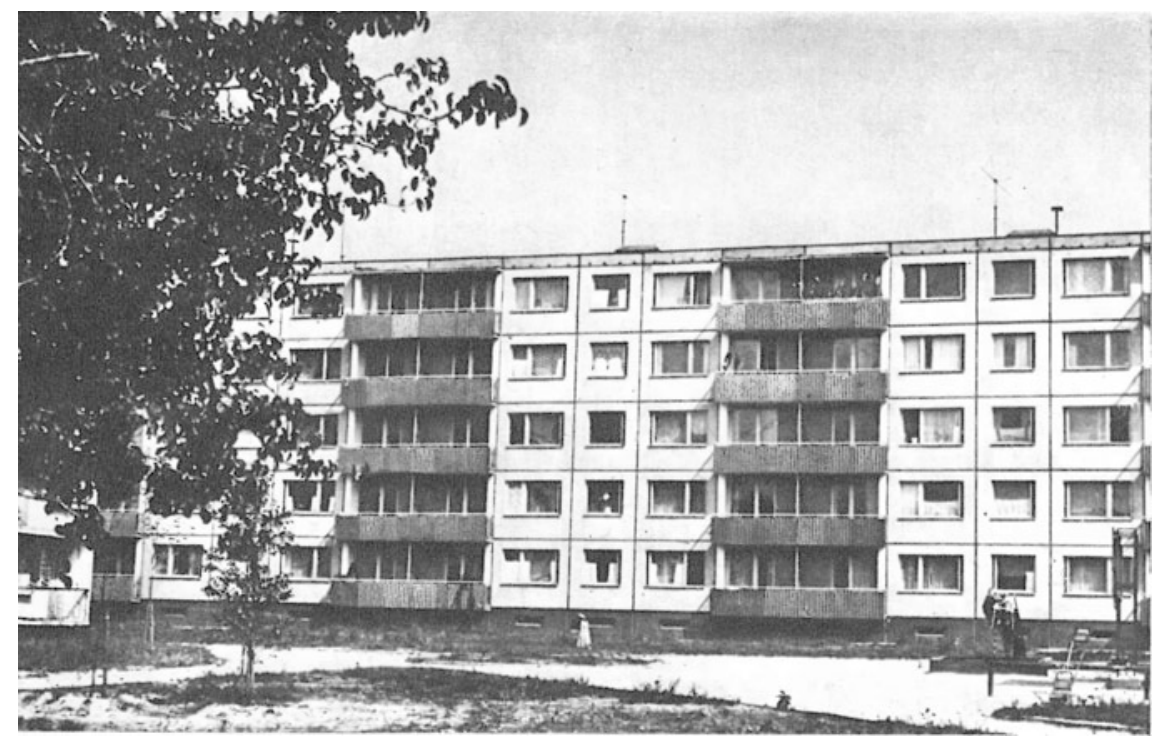

Fig. 4.4 An experimental large-panel apartment house (containing 75 units) based on standard series I-464. Source Žiburkus (1969), unpaginated 

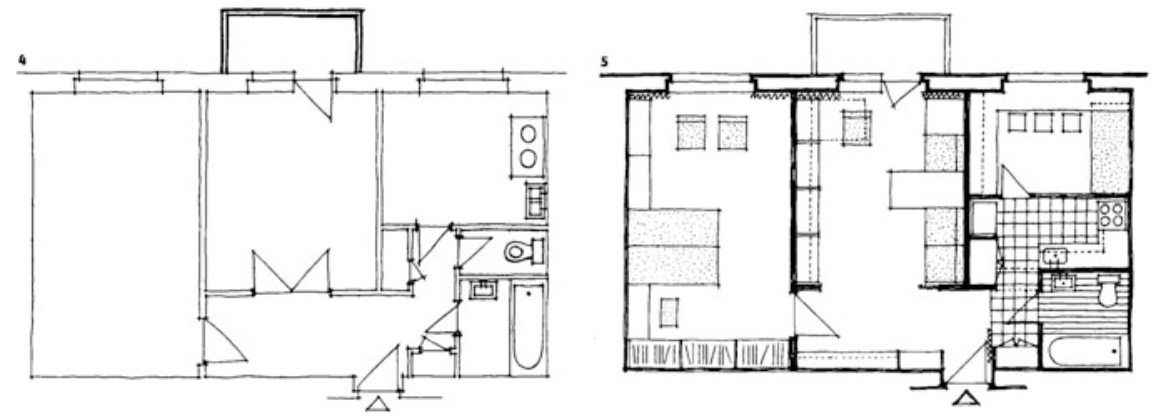

Fig. 4.5 An experimental apartment plan (right panel) compared to the standard apartment design (left panel). Architect Vytautas Nasvytis, 1961. Source Domov, 1967, no. 5, p. 22

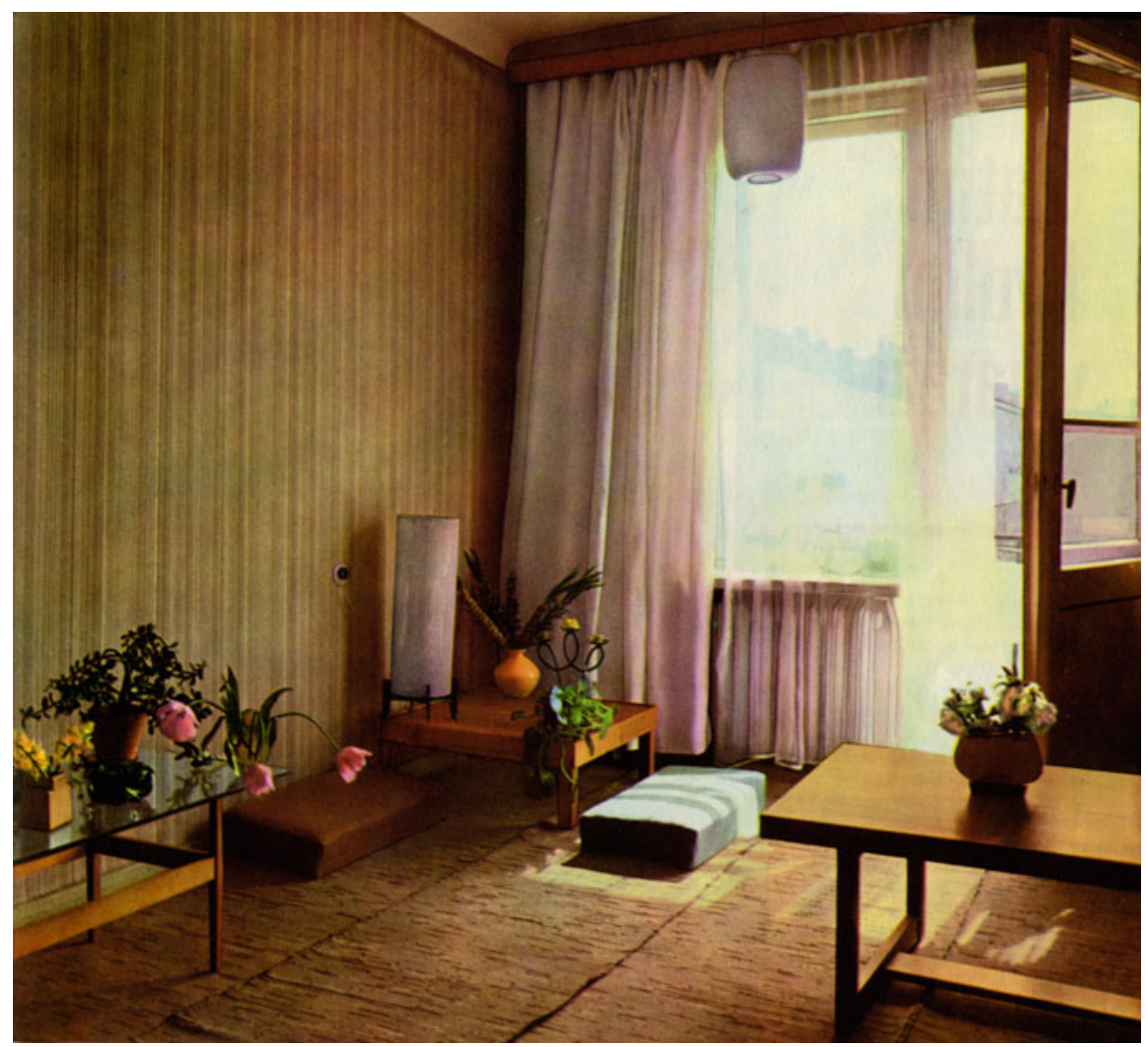

Fig. 4.6 Interior of an experimental apartment, architect Vytautas Nasvytis, 1961. Source Domov, 1967 , no. 5 , p. 23 

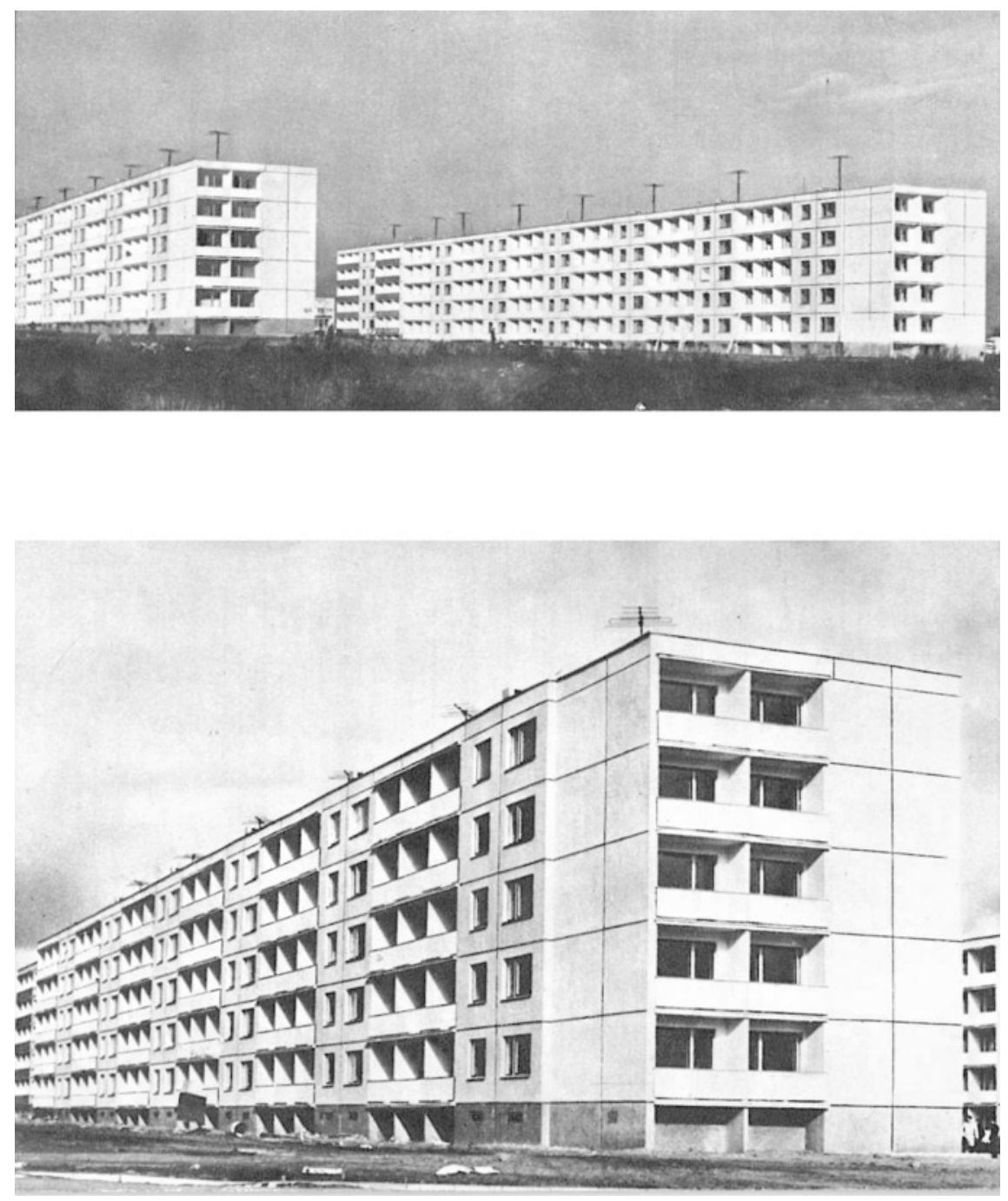

Fig. 4.7 An improved five-storey panel apartment building of the I-464-LI series (Krūminis group). Source Žiburkus (1969), unpaginated

363, 1.9-10). The detailed and meticulously planned Burbiškès project was never built; however, it provided architects with the experience they needed to engage more boldly in future experimentation with residential housing design.

Architect Bronius Krūminis, at the Urban Construction Design Institute, designed a second-generation series (I-464-LI, 1967) intended only for use in Lithuania. Krūminis started his career in the mid-1950s at the Vilnius Scientific Restoration Workshop and was responsible for the restoration of Trakai Lake Castle, an important historical national monument. However, harsh criticism from 
Moscow, for Lithuanians 'rebuilding feudal castles', put an end to these activities. The architect was demoted to work at the Department of Standard Design in Vilnius. However, even in his work there, one can detect his aesthetic approach and architectural ambition. He and his team-Algimantas Umbrasas, Vidas Sargelis and engineer Vaclovas Zubrus - developed the 'Lithuanian series' in close cooperation with Čekanauskas and Brèdikis, who from 1962 to 1963 designed Lazdynai, another large housing estate in Vilnius. In 1967, based on a standard wall length of $3.20 \mathrm{~m}$, they designed five-, nine- and twelve-storey prefabricated large-panel houses, with better apartment planning and loggias instead of balconies, also allowing the possibility of constructing houses on sloped terrain. The construction of these houses was temporarily halted in Lazdynai because the infrastructure was not yet ready, but went ahead in Žirmūnai, another large housing district. We will see later that Žirmūnai benefited greatly from these houses.

In 1970, Krūminis' group designed an experimental series - for construction in Lithuania between 1971 and 1975-which served as the basis for the 1973 third-generation $120 \mathrm{~V}$ panel housing series, distinguished by more façade relief detail, corner balconies and larger service rooms and kitchens. This new series can be seen as reflecting the architects' desire to make apartment planning more convenient and to bring greater volumetric diversity to their buildings. Within the constraints of standardised planning, his efforts constituted small steps toward architectural diversity in large housing estates. However, the lack of diversity was highlighted again in Decree No. 392, 'On Measures to Improve the Quality of Residential and Civil Construction', which was adopted in 1969 by the Soviet Council of Ministers and the Communist Party Central Committee and aimed to achieve greater architectural expressiveness, introduce unique cityscapes, and imbue residential areas with a stronger sense of local identity.

By the late 1970s and early 1980s, it was possible to see many more manifestations of regional identity and an increasingly individualistic approach to design in the building series designed exclusively for the coastal city of Klaipèda (Krūminis, Sargelis, Zubrus and Jonas Stanislovaitis, an engineer with the Klaipeda Panel Building Factory, series 1-120-PSS, 1980). These incorporated a central pattern of corner balconies and enclosed terraces with red brick walls-considered to be typical of the Klaipèda region - conceptually developed by architect Gytis Tiškus. Another innovation in mass-produced apartment construction was the introduction of an $11 \mathrm{~m}^{2}$ hall leading to a terrace, heated attics and more spacious kitchens $\left(8.67 \mathrm{~m}^{2}\right)$.

Architects also transferred their innovation into the realm of design competitions, hoping to obtain the coveted 'experimental project' status. An attempt at improving the quality of standardised designed apartment blocks was made in Estonia in 1971, when the minimum residential design standards were eased. The ensuing architectural competition produced a series of apartment blocks made from local materials, which were called 'Masso houses' after the architect Miia Masso. These buildings — often unplastered red brick buildings — can be encountered all across Estonia (Väljas and Lige 2015, pp. 61-62). 
In 1982, Krūminis' group also submitted an experimental design for a brick residential building that included a new floor plan for apartment units and the possibility of joining living rooms with the entrance hall, along with kitchens equipped with electric stoves. In this way, each unit could have about $30 \mathrm{~m}^{2}$ of combined space without violating any regulations on total apartment unit living space. The architects also proposed three different construction type options: brick support walls, prefabricated and monolithic construction. More and more buildings were constructed using brick, incorporating an increasing diversity of composition. Proposals were made to design a series of residential buildings suited specifically to the three Baltic republics, incorporating materials typically found in the region. However, the great majority of experimental designs were never utilised, or were implemented with considerable modifications, usually hopelessly simplified.

\subsection{Nordic Influence}

The influence of Nordic design is often emphasised in analyses of Baltic design of the Soviet period. Mart Kalm noted that when new residential districts were built among trees in existing pine forests, Tapiola was frequently cited as an inspiration - this happened in Āgenskalna Priedes in Riga, Mustamäe in Tallinn and Lazdynai in Vilnius (Kalm 2012b, p. 38). Triin Ojari also noted that Mustamäe, with its central multifunction shopping and entertainment centre, was akin to Vällingby and Tapiola (Ojari 2004, p. 69). Indeed, as opportunities for tourist travel and foreign exchange programmes increased in the late 1950s, the Soviet Architects' Union began to organise professional delegations that included several representatives from each of the Baltic republics, dispatched on fact-finding missions to both the socialist and 'capitalist' countries.

The favourable Soviet view of Scandinavia as a whole - friendly relations with Finland and Sweden in particular - the progressive approach to residential construction in these countries, and the proximity of the Baltic republics to Scandinavia all led to the Nordic region becoming a benchmark for Baltic modernists, with Finland the most frequently visited country for study trips. Estonia developed the closest relationship with Finland not only because of the closely related language but because of the direct ferry line which opened in the 1960s.

The first official fact-finding delegation to Finland, in June 1959, consisted of 21 specialists from Latvia, Estonia, Lithuania and the city of Leningrad (Materials on the visits of the Soviet architects to foreign countries, 1959, RGALI, f. 674, op. 3, d. 1598, p. 30). Mart Kalm believes that in their memoirs, architects slightly exaggerated the Nordic impact because they wanted to look more western. But, from the recollections of the Lithuanian architects, one can sense that Finnish Modernism really changed their understanding of the essence of architecture. Vytautas Čekanauskas, a member of the group recalled: 'There, we really felt the architecture' (V. E. Čekanauskas, personal communication, December 11, 2006). In 1960, three missions to Finland were organised, including 90 Soviet architects with one 
delegation made up exclusively of nearly 30 Lithuanian architects (Materials on the visits of the Soviet architects to foreign countries, 1960, RGALI, f. 674, op. 3, d. 1625, p. 68). A new directive issued by the Central Tourist Excursion Bureau on 31 January 1959 made foreign travel easier to organise for local trade union administrations in the republics, facilitating continuing visits by Lithuanian architects to Finland in 1961, 1963, 1964, and in later years.

The visiting Lithuanian architects brought home strikingly emotional impressions. Many of them referred to Finland as a symbol of modern architecture that influenced their later work. The Nasvytis brothers asserted that they embraced 'a Finnish-Nordic way of thinking, perceived through the works of Ervi, Aalto, and others' (Mačiulis 2007, p. 102). Čekanauskas remembered the trip having a lasting impression on him. Seeing the suburb of Tapiola and meeting its architect Ervi was, for Čekanauskas, an indescribable event (V. E. Čekanauskas, interviewed by John V. Maciuika, 1992). Vytautas Bredikis recalls: 'good, humane architecture ... a masterful harmony of buildings and nature' (V. Brèdikis, personal communication, August 2, 2011). Documents from personal archives show that many who visited Finland admired works by Alvar Aalto and Reima Pietilä, and used Finnish Modernism as inspiration. Architects admitted that the materials and design processes they used, as well as the composition of their designs within their natural context, all changed after their foreign trips.

\subsection{Recipients of Architectural Excellence Awards: Žirmūnai, Lazdynai and Väike-Õismäe}

\subsection{1 Žirmūnai}

Soviet architectural awards had a strong ideological and didactic role. With the introduction of the USSR State Prize (which was lower in rank to the Lenin Prize) in 1966, one can observe a more equal distribution of prizes among the Soviet Republics and the introduction of a more diverse functional typology of architecture among political monuments and significant public buildings, which were the only types previously to receive awards. The D-18 microrayon of the Žirmūnai residential area-built between 1962 and 1964 in Vilnius, Lithuania-became the first Soviet housing development to receive the USSR State Prize for urban residential design in 1968. It was also the first mass housing estate to receive an award at the first Soviet-wide review of the country's architecture, organised in 1967 in Moscow. From a field of 167 designs submitted for state recognition, the first prize was awarded, by unanimous decision, to the D-18 microrayon. The press signalled it as a turning point in Soviet architecture (Barkhin 1968, p. 5). Politically this recognition was aimed at finding models to be followed in developing Soviet mass housing architecture.

A young urban planner, Birutė Kasperavičienè (1926-1976), began designing new residential microrayons in Vilnius in 1956, and designed the first new 
industrial town, Elektrènai, for 4000 residents in Soviet Lithuania in 1960. In her later D-18 project, Kasperavičiene preserved the natural downhill of the river bank. She had the benefit of using the improved standard house I-464 series, which was developed at the Vilnius Urban Construction Design Institute. Žirmūnai became an experimental site where some of the modernist ideas were introduced; for example, the new nine-storey panel house for single persons (architect Enrikas Tamoševičius) along with the shopping and service centre of the microrayon (a standard design modified by architect Aleksandras Aronas) that was decorated with public art (Figs. 4.8 and 4.9).

When Žirmūnai was nominated for the USSR State Prize in 1968, the award committee noted that the planning of the site was not exceptional. However, they singled out the improvement in designs of standard five-storey houses: 'The site's value stems from a successful implementation of mass housing using a creative approach' (USSR State Prizes, April 1968, RGALI, f. 2916, op. 2, d. 396, p. 167). The committee expressed their belief that the development of the standardised building series would benefit mass housing throughout the country (particularly if the director of the panel factory was involved). Accordingly, a proposal was made to make awards to the structural engineer and the producer of panel housesarchitect Bronius Krūminis and structural engineer Vaclovas Zubrus, representing the developers of the standard I-464 series, and Šmuelis Liubeckis, the director of the Vilnius Factory of Panel Construction - in addition to Kasperavičienè, the planner. It was explicitly stated that Žirmūnai served as proof 'that industrial housing can be diverse: it can have its own character and it can avoid becoming a

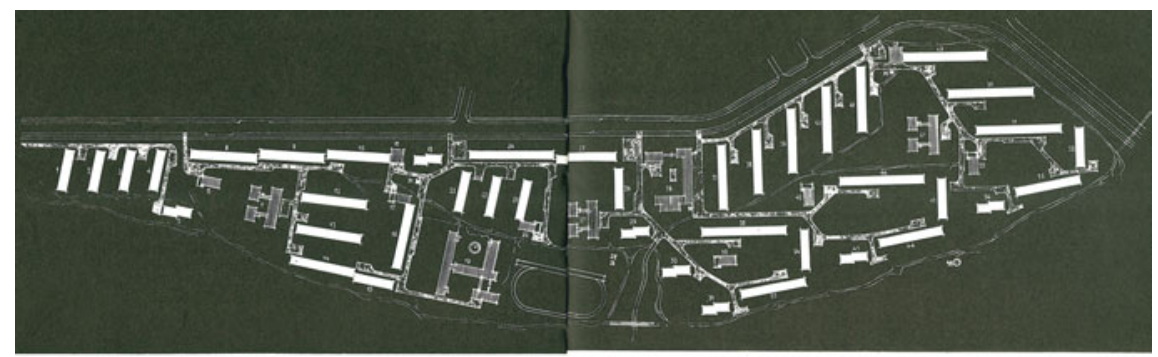

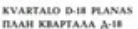
miN of CIT noox D.18.

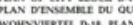

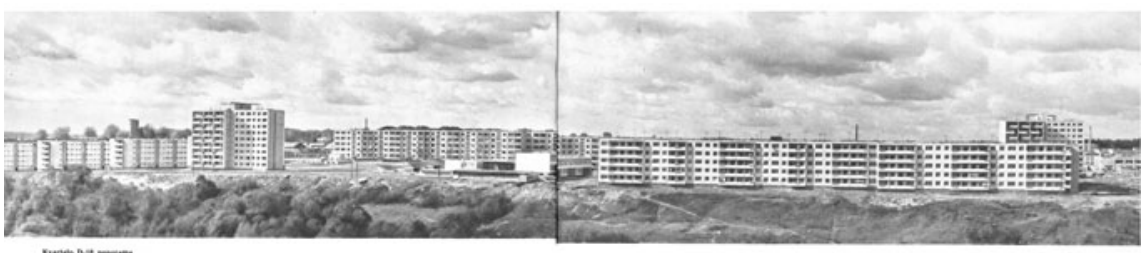

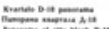

-

Figs. 4.8, 4.9 Plan and view of D-18 microrayon of the Žirmūnai residential area, 1964. Source Žiburkus (1969), unpaginated 
[nationwide] cliché' (USSR State Prizes for the year 1968, October, RGALI, f. 2916, op. 2, d. 397, p. 15).

After Žirmūnai, almost all new industrial cities and significant new mass housing residential areas were awarded the USSR State Prize: Navoii (new industrial town, 1969), Togliatti (new industrial town, 1973), Zelenograd (new architectural complexes, 1975), Shevchenko (new industrial town, 1977), Troparevo (residential area in Moscow, 1980), Pobeda (residential area in Dnepropetrovsk, 1983), VäikeÕismäe (residential area in Tallinn, Estonian SSR, 1986), and residential areas of Eastern Minsk (Belarussian SSR, 1989). It was not until 1974, however, that the Lenin Prize, the Soviet Union's highest award, was conferred on a large mass housing estate. Lazdynai, a new suburb of Vilnius, was said to represent a qualitatively different modernist town planning concept in the Soviet space.

\subsubsection{Lazdynai}

Planning for Lazdynai, a large housing estate for 40,000 residents, grouped into four microrayons, started in 1962 (constructed in 1967-1973). Vytautas Brèdikis and Vytautas Čekanauskas were commissioned to design the estate. It was not a routine commission, although they already had experience with planning Burbiškès. But by 1962, these young architects were already promising in the field of custom design. They emphasised that they were not regular planners of large housing estates and were capable of presenting innovative ideas: 'We were naturally influenced by the aim of making it [Lazdynai] different—of making it better' (V. Brèdikis, interviewed by John V. Maciuika, 1992, p. 8). In later interviews (1992, 2006, 2011), they spoke about the considerable influence on their designs of Finnish (Tapiola), Swedish (Vällingby, Årsta) and modern French (Toulouse-Le Mirail) suburban projects. Both Brèdikis and Čekanauskas highlighted three features they considered most important in differentiating Lazdynai from other Soviet large housing estates (Fig. 4.10).

The first one was the naturally hilly and well-forested site-features that would be preserved in the final landscape design. This was closely connected to the second component - improvements to the I-464 series five- and nine-storey buildings (with Bronius Krūminis, see above), by adding twelve-storey towers. The architects advocated the placement of five- and nine-storey housing blocks perpendicularly across the sloping terrain to create a unique silhouette for the new community: 'We wanted to draw up a special design for each of the buildings, but it was not possible then-we could not build two-storey cottages, for example. Of course, we modified the standard series here, in Lithuania, but the rules and norms were from Moscow' (V. Bredikis, interviewed by John V. Maciuika, 1992, p. 15). Čekanauskas believed that for Lithuania, it was a great opportunity to design its own housing series I-464-LI: 'Who else in the Soviet Union could design their own series except Moscow and Leningrad?' (V. E. Čekanauskas, interviewed by John V. Maciuika, 1992, p. 15). Though the production of these new types of building was a challenge 


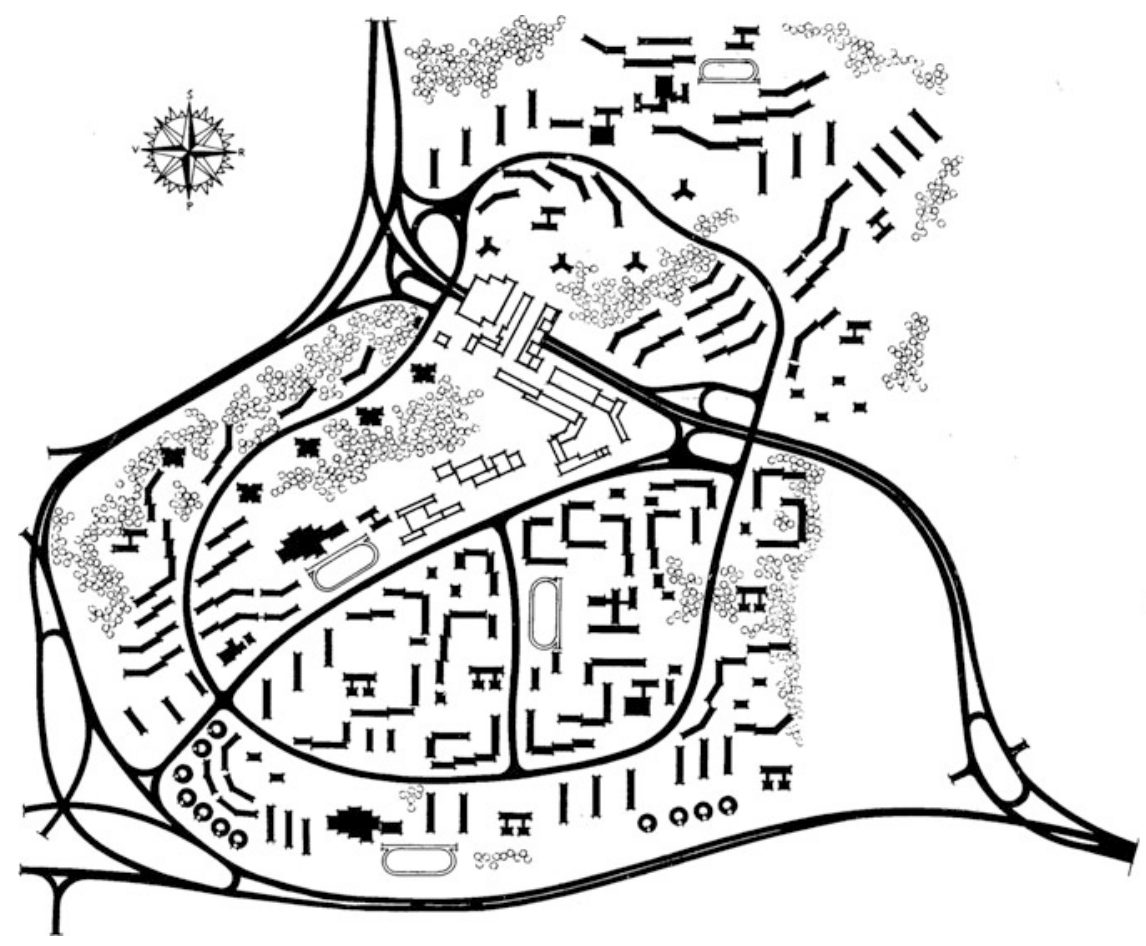

Fig. 4.10 Master plan for Lazdynai, 1967. Source Balčiūnas (1983), p. 3

for the Vilnius Panel Construction Factory, the architects believed that institutional nationalism (strong personal connections between architects and local Communist Party and municipal leaders) played a role when the need arose to defend the innovative designs at Gosstroi: 'we managed to persuade the producers' (V. Brèdikis, interviewed by John V. Maciuika, 1992, p. 8) (Figs. 4.11, 4.12 and 4.13).

Although planners were committed to adapting the standard design in public buildings, the centres of the three microrayons were each given a unique layout complete with public art. After two standard schools were constructed, young architect Česlovas Mazūras introduced an original terraced approach (while still using prefabricated components) that incorporated the sloping terrain and used different materials (red brick in combination with concrete panels).

The third component, highlighted by Čekanauskas, was the integrated construction of the environment, infrastructure and landscape design. He was impressed by the landscape design of the new Swedish housing suburbs (from books, since he did not visit Sweden) and stated that the low density of houses, together with the landscape design, made Lazdynai different to Russian large housing estates where incorporation of these features was never completed. He also often used the phrase 'good taste' in his interviews (1992, 2006) (Figs. 4.14, 4.15 and 4.16). 

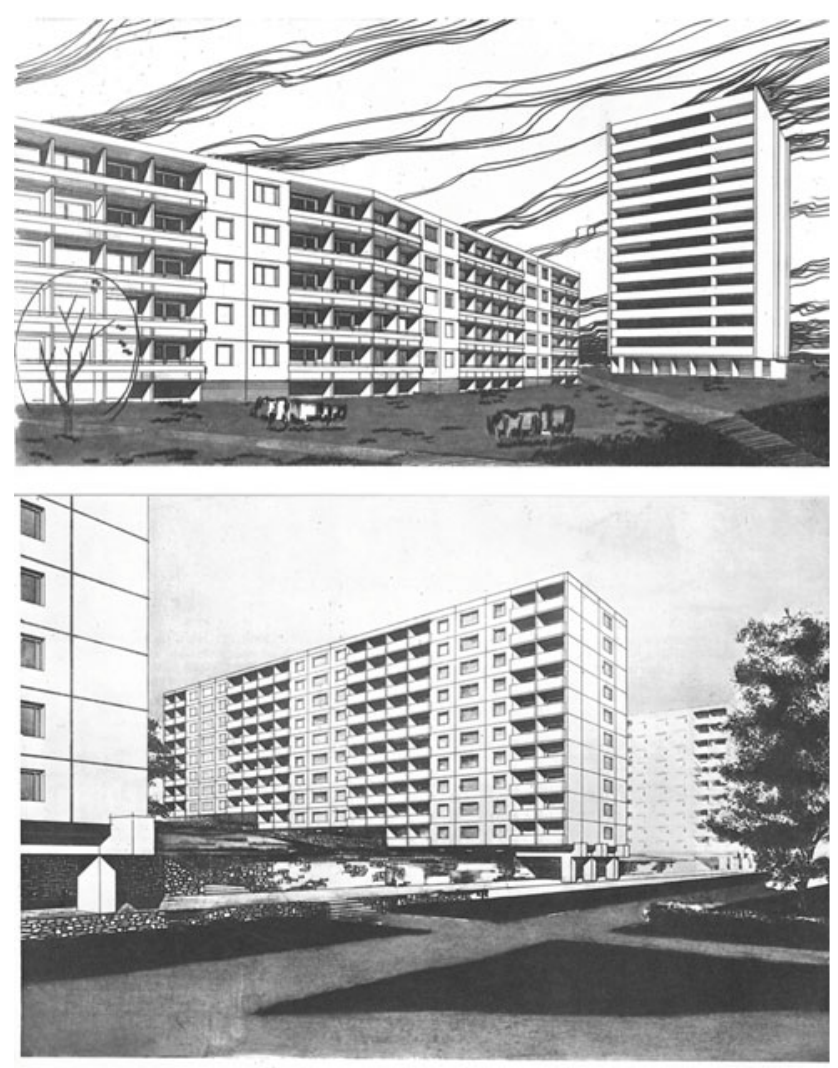

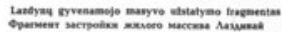

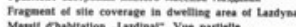

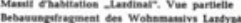

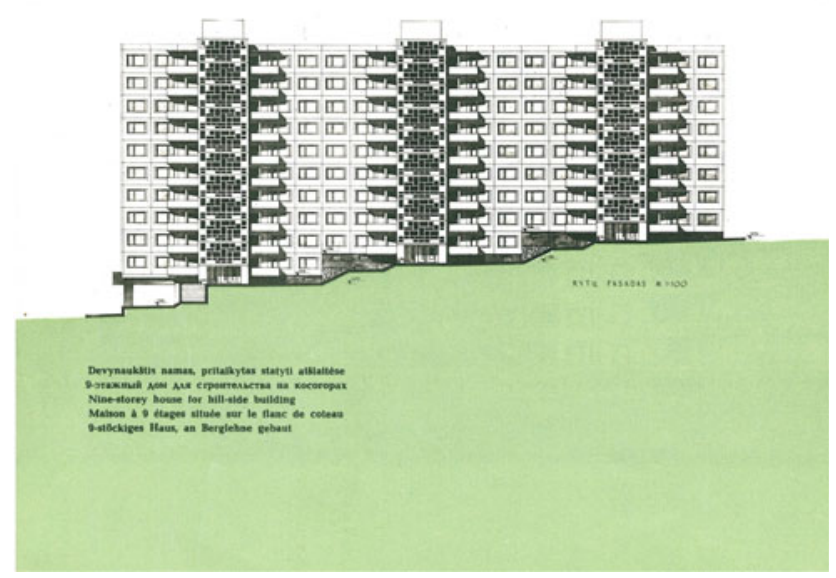

Figs. 4.11, 4.12, 4.13 Improved five- and nine-storey panel building series I-464-LI. Source Žiburkus (1969), unpaginated 
Figs. 4.14, 4.15, 4.16 Views of Lazdynai in the 1980s.

Source P. Petkevičius,

Balčiūnas (1983), p. 6, 10, 14
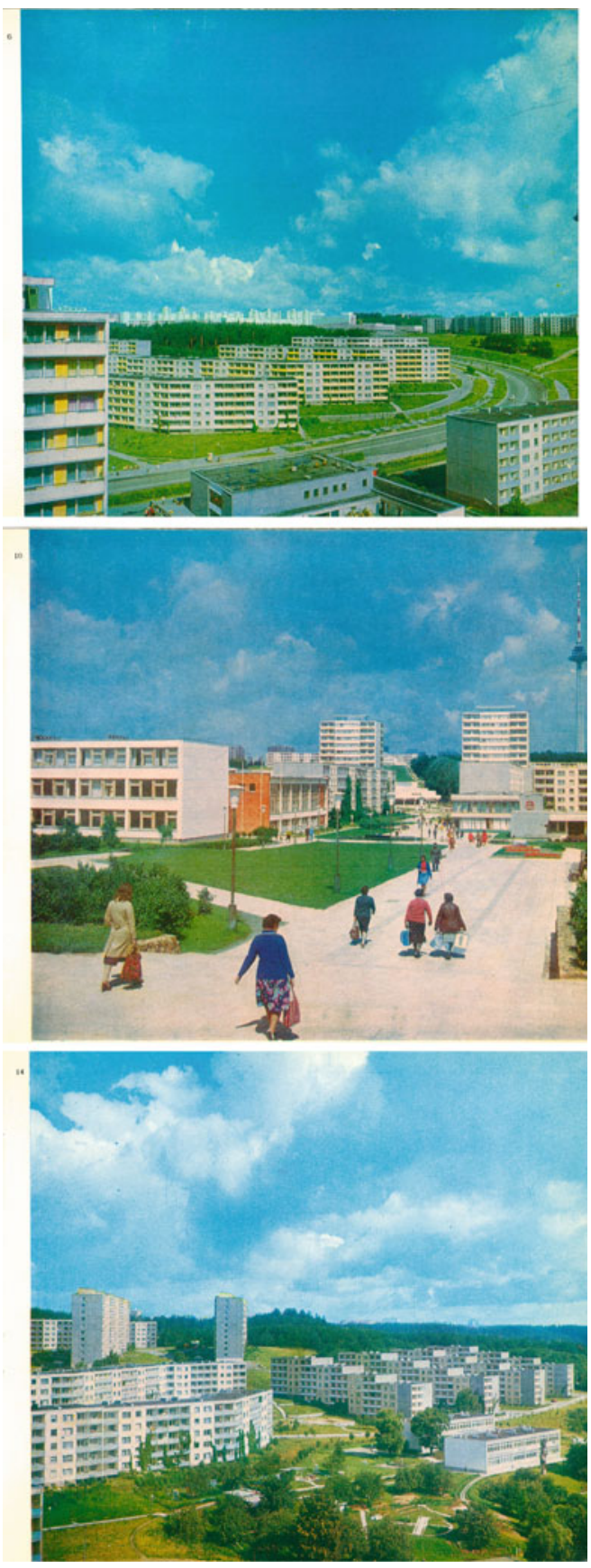
The nomination of Lazdynai for the Lenin Prize in 1974 proceeded smoothly at the Architectural Section and at the Plenary (Lenin Prizes for 1974, April, RGALI, f. 2916, op. 2, d. 751, c. 28-29), since the uniqueness of the site was confirmed by Gosstroi and the Architectural Section members' visit to Lazdynai (including a helicopter tour) (Lenin Prizes for 1974, February, RGALI, f. 2916, op. 2, d. 781, c. 30; Lenin Prizes for 1974, April, RGALI, f. 2916, op. 2, d. 750). Even the large number of individuals nominated to receive the award - six in total, since several officials, such as the Senior Architect of Vilnius city and the head of the construction unit, were also included - provoked little in the way of discussion. Thus, Lazdynai became the first mass housing urban design to be recognised with the most prestigious Soviet national prize. Clearly, the district's design had been overseen by two very talented architects, with many other specialists (nearly 150) contributing to the details. Politically, Lazdynai was used to demonstrate that panel construction is still valid - and does not require major changes — only a touch of 'landscape design'.

\subsubsection{Väike-Õismäe}

The Väike-Õismäe district in Tallinn, Estonia was designed between 1968 and 1969 and built from 1971 to 1975 (architects Mart Port and Malle Meelak) for 45,000 residents. It had already received attention during the process of its design; it was widely featured in the press as a forward-looking design and was even presented as a Soviet achievement in residential planning in the well-known special issue of an international architectural journal dedicated to Soviet architecture (L'Architecture d'au jourd'hui, 1970, pp. 60-61). It was then regarded as a fantasy come true-a Modernist utopian urban space with a geometric plan that could only be perceived from high above (Väljas and Lige 2015, p. 169). Its novelty was perceptible in the new type of planning - the architects refused the traditional division of the area into three microrayons and organised the entire residential area around the central pond, following the idea of a circular town. The green belt around the central pond was reserved for pedestrian and cycle traffic, schools and child care centres. The main road encircling Väike-Õismäe was for public transport and vehicle traffic. The inner circle of the street was planned as quadrangular blocks of nine-storey apartment houses. Sixteen-storey tower blocks were located adjacent to the bus stop and low-rise local supermarkets with customer service buildings. The outer circle of the main street consisted of five-storey apartment houses (Lankots 2010, p. 44). VäikeÕismäe was the only fully completed large housing estate of the three large housing areas that were built in Tallinn from the 1960s to the 1990s. It was also well known for its experimental character. However, it only received the State Prize in 1986 (the area was completed in 1984), when all its novelty was already dated and its shortcomings had become apparent, such as the difficulty for residents in orientating themselves and monotony of houses. 
The three large housing estates which received awards well reflect novelties and experimentation in planning ideology of the period in which they were built. Žirmūnai can be viewed as an ideological representation of creative approach to planning in large housing district, which should have encouraged other planners and builders to experiment. Lazdynai and Väike-Õismäe can be seen as real visions, involving a lot of effort from well-known architects, with the aim of creating an architecturally distinctive housing area.

\subsection{Conclusion}

The recognition that Baltic urban planners received in the late Soviet period can be viewed in two ways. Though a considerable role was played here by the 'good reputation' earned by the designs of Žirmūnai and Lazdynai, Baltic approaches to microrayon design in general were notable within the general Soviet context for their architectural originality. First and foremost, these districts were small in size and constructed in suburbs well chosen for their natural characteristics with the attempt to give each new neighbourhood a sense of uniqueness, drive improvements in industrialised housing construction and assembly as well as environmental clean-up projects. It could be said that these efforts became the defining characteristics of Baltic residential urban planning. With one eye on the West, Baltic architects, planners and engineers tried to bring a certain level of dignity to otherwise standardised Soviet large housing estates.

It is evident that Baltic architects sought to avoid standardised designs, which immediately devalued any creative aspect of the planning process. Standard designs quickly became obsolete, both technically and morally. For all practical purposes, their designers remained unknown to the public at large. It is also evident that, although architects in many Soviet Republics began to shun mass construction projects and conceded the initiative to engineers, the design of mass housing in Lithuania and Estonia was always overseen by professional architects. Despite standardisation and the very limited choice of materials and building types, there were attempts to improve the living environment of mass-produced architecture. Such efforts were made easier by the existence of professional relationships developed between designers, the Communist Party and local administration officials, and the heads of construction material enterprises. Nevertheless, a stagnant bureaucracy and construction industry ensured that most experimental projects remained in the desk drawers and archives of planning institutions, even as clusters of mass-constructed apartment buildings encircled most Baltic cities and towns.

Acknowledgements This research was funded by grant no. S-MOD-17-21 from the Research Council of Lithuania. The author also expresses appreciation to the Juozas Sidas Foundation at Vilnius University, Faculty of History. 


\section{References}

Anderson R (2015) Russia. Reaktion books, London

Balčiūnas V (1983) Lazdynai. Mokslas, Vilnius

Barkhin M (1968) Смотр достижений советской архитектуры [Review of Soviet architectural achievements]. Архитектура СССР 1968(1):5-20

Budreika E (1971) Architektura Sovetskoi Litvy (Architecture of Soviet Lithuania). Stroiizdat, Leningrad (in Russian)

Caldenby C, Wedebrunn PO (eds) (2010) Living and dying in urban modernity. Royal Danish Academy of Fine Arts, School of Architecture, Copenhagen

Caldenby C, Wedebrunn PO (eds) (2013) Survival of modern. From cultural centres to planned suburbs. Royal Danish Academy of Fine Arts, School of Architecture, Copenhagen

Cinis A (2007) Signs of modernism in the architecture of Soviet Latvia between 1960-1980. In: Kervanto-Nevanlinna A (ed) Industry and modernism. Companies, architecture, and identity in the nordic and Baltic Countries during the high-industrial period. Studia Fennica Historica 14, Finnish Literature Society, Helsinki, pp 172-183

Crowley D (2009) Socmodernism and the architecture of leisure in Eastern/Central Europe in the 1960s and 1970s. In: Helme S (ed) Different modernisms, different avant-gardes: problems in Central and Eastern European Art after World War II. Proceedings of the Art Museum of Estonia, Tallinn, pp 246-258

Drèmaite M (2010) The (Post-)Soviet built environment: soviet-western relations in the industrialised mass housing and its reflections in Soviet Lithuania. Lith Hist Stud 15:11-26

Drèmaitė M (2017) Baltic modernism. Architecture and housing in Soviet Lithuania. Dom Publishers, Berlin

Kalm M (2012a) An apartment with all the conveniences was no panacea: mass housing and the alternatives in the Soviet Period Tallinn. Arch Urban J Arch Town Plan Theory 47:189-202

Kalm M (2012b) Baltic modernisms. In: Ritter K, Shapiro-Obermair E, Steiner D, Wachter A (eds) Soviet modernism 1955-1991. Unknown history. Park Books, Zuerich, pp 33-45

Kalm M, Ruudi I (eds) (2005) Constructed happiness: domestic environment in the Cold War Era, (2005). Estonian Academy of Arts, Tallinn

Kosenkova YL (2013) Представления о целостном организме города в период изменения творческой направленности советской архитектуры. In: Kazakova OV (ed) Эстетика оттепели: новое в архитектуре, искусстве, культуре. Российская политическая энциклопедия (РОССПЭН), Москва, pp 15-76

Krastinš̌ J (2013) Āgenskalna Priedes a late 1950s Housing project in Riga: surviving pine trees in the city. In: Caldenby C, Wedebrunn PO (eds) Survival of modern. From cultural centres to planned suburbs. Royal Danish Academy of Fine Arts, School of Architecture, Copenhagen, pp 92-101

Krastinš J, Strautmanis I, Buka O, Asaris G (1987) Architektura Sovetskoi Latvii (Architecture of Soviet Latvia). Stroiizdat, Moskva (In Russian)

Kurg A (2009) Architects of the Tallinn School and the critique of Soviet Modernism in Estonia. J Arch 1:85-108

Lankots E (2010) Väike-Õismäe. In: Caldenby C, Wedebrunn PO (eds) Living and dying in urban modernity. Royal Danish Academy of Fine Arts, School of Architecture, Copenhagen, pp 4446

Maciuika JV (1999) East block, west view: architecture and lithuanian national identity. Tradit Dwell Settlements Rev XI(1):23-35

Mačiulis A (2007) Architektai Algimantas ir Vytautas Nasvyčiai [Architects Algimantas and Vytautas Nasvytis]. Vilniaus dailès akademijos leidykla, Vilnius

Metspalu P, Hess DB (2018) Revisiting the role of architects in planning large-scale housing in the USSR: the birth of socialist residential districts in Tallinn, Estonia, 1957-1979. Plan Perspect 33(3):335-361. https://doi.org/10.1080/02665433.2017.1348974 
Meuser P (2016) Seismic modernism. Architecture and housing in Soviet Tashkent. DOM Publishers, Berlin

Meuser P, Zadorin D (2015) Towards a typology of Soviet mass housing. Prefabrication in the USSR 1955-1991. Dom Publishers, Berlin

Minkevičius J (1964) Miestai vakar, šiandien, rytoj (Cities of yesterday, today, and tomorrow). Valstybinè politinès ir mokslinès literatūros leidykla, Vilnius

Minkevičius J (1987) Architektura Sovetskoi Litvy (Architecture of Soviet Lithuania). Stroiizdat, Moskva (in Russian)

Ojari T (2004) Elamispind. Modernistlik elamuehitusideoloogia ja Mustamäe [Floor space. The modernist residential housing ideology and Mustamäe]. Kunstiteaduslikke Uurimusi/Stud Art Arch 13(2):42-70

Osnovy sovetskogo gradostroitelstva Tom 2 [Principles of town planning in the Soviet Union Vol. 2] (1967) Stroiizdat, Moscow

Peras J (1958) Daugiabutis gyvenamas namas (Multi-apartment house). Valstybinè politinès ir mokslinès literatūros leidykla, Vilnius

Ritter K, Shapiro-Obermair E, Steiner D, Wachter A (eds) (2012) Soviet modernism 1955-1991. Unknown history. Park Books, Zuerich

Ruble BA (1993) From khrushcheby to korobki. In: Brumfield WC, Ruble BA (eds) Russian housing in the modern age: design and social history. Cambridge University Press, Cambridge, pp 232-270

Väljas M, Lige CD (2015) Elav Ruum: sajand Eesti arhitektuuri/Space in motion: a century of Estonian Architecture. Museum of Estonian Architecture, Tallinn

Volkov L (1987) Architektura Sovetskoi Estonii (Architecture of Soviet Estonia). Stroiizdat, Moskva (in Russian)

Volkov L, Kruusimagi Y (1972) Architektura Sovetskoi Estonii (Architecture of Soviet Estonia). Stroiizdat, Moskva (in Russian)

Zakamennijs O (1966) Laikmetiga arhitektura padomju Latvija (Contemporary Architecture of Soviet Latvia). Liesma, Riga (parallel text in Latvian and Russian)

Žiburkus J (ed) (1969) Vilniaus namų statybos kombinatas (Vilnius house building factory). (1969). Ministry of Construction of the Lithuanian SSR, Vilnius

Open Access This chapter is licensed under the terms of the Creative Commons Attribution 4.0 International License (http://creativecommons.org/licenses/by/4.0/), which permits use, sharing, adaptation, distribution and reproduction in any medium or format, as long as you give appropriate credit to the original author(s) and the source, provide a link to the Creative Commons license and indicate if changes were made.

The images or other third party material in this chapter are included in the chapter's Creative Commons license, unless indicated otherwise in a credit line to the material. If material is not included in the chapter's Creative Commons license and your intended use is not permitted by statutory regulation or exceeds the permitted use, you will need to obtain permission directly from the copyright holder. 